Article

\title{
Building Ownership, Renovation Investments, and Energy Performance-A Study of Multi-Family Dwellings in Gothenburg
}

\author{
Mikael Mangold ${ }^{1, *}$, Magnus Österbring ${ }^{2}$, Conny Overland ${ }^{3}{ }^{(\mathbb{C}}$, Tim Johansson ${ }^{4}$ and \\ Holger Wallbaum 2 (iD) \\ 1 City Development, Research Institutes of Sweden, 41261 Gothenburg, Sweden \\ 2 Architecture and Civil Engineering, Chalmers University of Technology, 41296 Gothenburg, Sweden; \\ magost@chalmers.se (M.Ö.); holger.wallbaum@chalmers.se (H.W.) \\ 3 Department of Business Administration, University of Gothenburg, 40530 Gothenburg, Sweden; \\ conny.overland@handels.gu.se \\ 4 Department of Civil, Environmental and Natural Resources Engineering, Luleå University of Technology, \\ 97187 Luleå, Sweden; tim.johansson@ltu.se \\ * Correspondence: mikael.mangold@ri.se; Tel.: +46-70-297-9778
}

Received: 28 March 2018; Accepted: 17 May 2018; Published: 22 May 2018

\begin{abstract}
The European building stock was renewed at a rapid pace during the period 1950-1975. In many European countries, the building stock from this time needs to be renovated, and there are opportunities to introduce energy efficiency measures in the renovation process. Information availability and increasingly available analysis tools make it possible to assess the impact of policy and regulation. This article describes methods developed for analyzing investments in renovation and energy performance based on building ownership and inhabitant socio-economic information developed for Swedish authorities, to be used for the Swedish national renovations strategy in 2019. This was done by analyzing measured energy usage and renovation investments made during the last 30 years, coupled with building specific official information of buildings and resident area characteristics, for multi-family dwellings in Gothenburg $(N=6319)$. The statistical analyses show that more costly renovations lead to decreasing energy usage for heating, but buildings that have been renovated during the last decades have a higher energy usage when accounting for current heating system, ownership, and resident socio-economic background. It is appropriate to include an affordability aspect in larger renovation projects since economically disadvantaged groups are over-represented in buildings with poorer energy performance.
\end{abstract}

Keywords: renovation extent; energy retrofitting; rent affordability; tenure; energy performance certificate; decision support

\section{Introduction}

In 2010, buildings accounted for $32 \%$ of total global final energy usage [1]. The European Directive $2012 / 27 / E U$ [2] requires member states to have a strategy for renovation of the building stock with the target of reducing energy usage by $20 \%$ by 2020 compared with 1990. In many European countries, the building stock increased at a rapid pace during the period 1950-1975 [3]. This aging building stock needs to be renovated, and there is a possibility to introduce energy efficiency measures in the renovation process $[4,5]$.

Building condition, building ownership, and rent affordability determine what kind of renovation measures are possible and optimal [6]. Furthermore, tenure types, building regulations, construction practices etc. vary between different contexts, which increases the need for country-specific studies 
on renovation investments and energy performance [7-9]. The authors have developed methods for analyzing investments in renovation and building energy performance based on comprehensive building-specific information that can be used to analyze subgroups of building owners and specific socio-economic inhabitant groups. This was done for the Swedish case and to be used by the Swedish authorities. The paper tries to answer the question how can merged official comprehensive building specific information be used to describe the developments in the multi-family dwelling stock?

There are several studies on how ownership and socio-economic area conditions affect investment and energy performance. For rental multi-family dwellings, the landlord-tenant problem can be a barrier to energy retrofitting and renovation [10-14]. The multi-family dwellings that are resident-owned also have internal barriers to larger investments in energy retrofitting [15-17]. There is also not a consensus on which parameters should be included in an optimization of renovation projects. For instance, renovations financed by increased rents in socio-economically disadvantaged areas risk aggravating societal inequities [18-20].

The purpose of this article is to describe quantitative methods developed for analyzing how overall renovation progress and improved energy performance of buildings is related to ownership structures. The methods were developed for the multi-family dwellings in Gothenburg, Sweden, with the intention of being applicable for the entire national building stock in the update of the national strategy of energy efficient renovation in 2019. This article also contributes within the field of analysis of building specific information coupled with measured energy usage, also presented as Building Energy Epidemiology by the International Energy Agency, Annex 70. Countries have different registers and specific ways of storing and working with information. This article presents the Swedish case and methods developed for working with Swedish building specific information.

Building specific energy usage for all Gothenburg multi-family dwellings was gathered from Swedish Energy Performance Certificates (EPC). In most other counties in Europe the EPCs contain estimated energy usage, while in Sweden the EPCs should be issued by an certified energy expert that registers measured energy for heating from the 13 most commonly used heating sources, heating for tap water, and domestic electricity usage [21,22]. Renovation investments were deduced from official property taxation records. By aligning these datasets with building-specific information on ownership, tenure, and living-area socio-economic information, it is possible to analyze the progress toward the goals of reduced energy usage and decreased segregation. Michelsen et al. [23] also used measured energy usage from EPC data for German the building stock and made similar analyses focusing mainly on the difference between smaller and larger real estate owners. Michelsen et al. [23] found that larger real estate companies outperform smaller companies in terms of extensive renovations, but smaller companies can be better at continuous maintenance. This article compares real estate companies with other types of ownership. Albatici et al. [24] and Šijanec Zavrl et al. [25] merged mainly energy-related databases for the Italian and Slovenian building stock to model scenarios of developments toward energy efficiency. Our additional contribution is to work toward the development of methods that also include socio-economic parameters of building stock development.

Matschoss et al. [17] made a larger European summary of renovation policy that include tenure and found that incentives for condominium owners to energy retrofit buildings are needed in Europe to reach the 20-20-20 targets. This article sheds light on the renovation activities of multi-family dwellings in Sweden in two main ways. First, it describes methods developed for analyzing energy usage and investment in renovation in different ownership groups intended to be applied future analysis of impact of building regulations and subsidies. Second, we add to the literature on decision-making by presenting an empirical analysis of a large sample of homogeneous organizations, where one can distinguish between individual and social decision making.

\section{Real-Estate Ownership in Sweden}

To analyze the impact of regulations and subsidy schemes, it is necessary to distinguish between different ownership for which decision-making structures, taxation rules, subsidies, and the availability 
of funds are different. In addition, there is a variation between the ownership types in living area per person and in the resident profit or increased cost from improved living standards and energy performance.

Swedish multi-family dwellings are primarily of two tenure types: rental apartments or resident owned apartments, which is a type of tenure comparable with condominiums. Residents own a tradable share in a resident's organization that gives them the right to inhabit a specific apartment of the building. Member of the resident's organization are required to pay a membership fee toward maintenance and capital costs.

The rental apartments can be divided in two larger groups: municipally owned and privately owned [26]. From 1960 to 1975, a national initiative was initiated with the aim to build one million dwellings to cover an urgent housing need in Sweden [26,27]. The multi-family dwellings constructed during this period were constructed as privately owned rental apartments $(20 \%)$, municipal rental apartments (50\%), and resident-owned apartments (30\%) [26]. Details about the building age typology can be found in Table A1. The main construction types in the Gothenburg multi-family building stock are slab block, enclosed block, point block, and gallery access block.

Private real estate firms are for-profit organizations that typically are family controlled, though investment funds are growing in importance within this group. Private real estate firms span from private individuals that own one building to large firms that own properties nationally as well as internationally. The modus operandi of private building owners is expected to be that of for-profits in general-to maximize asset value over time. For this reason, renovation as investments in general by private building owners are more likely to take place in attractive areas where risk is lower. With lower risk, the value added to money invested is higher. Some variation should also be found between different private tenants in how they make decisions. For instance, large firms possess superior organizational capacity and have better access to external finance. This means that they are likely to be better equipped to make investments in general and thereby are more inclined to follow through with investments [23].

Municipality owned multi-family dwellings in Gothenburg consist of four large companies. Municipally owned apartments are located in both areas with higher and lower income. They differ from private firms as they, historically, have not had profits as an organizational goal. In fact, they have not even been allowed to make profits. Instead, their focus has been to provide sufficient and affordable housing. The pro-social goal of these firms indicates that they are more inclined to make investments in lower income areas. Renovation can also be more common in municipally owned building due the fact that these companies have had access to cheaper finance through municipal bails.

Resident-owned apartments differ from both private and municipal housing companies. To start with, they are not subject to rental regulation. That means that they can increase their member fees for supplying value-adding features to their members in ways that rental housing companies cannot. For instance, if a private real estate company invests in reduced energy usage and improved indoor climate, this investment has to be carried by the cost reductions from the lower energy usage only. They are not allowed to charge a higher rent for the improved indoor climate and area branding. The group of resident-owned apartments, by contrast, can internalize such features in their member fees. This should increase the scope for more far-reaching renovation.

However, investments in resident-owned buildings are dampened by obstacles associated with social choice. In particular, if the membership fee is increased, the market value of the apartment decreases, making it difficult for all tenants to agree on a time when renovation should happen. Mastschoss et al. [17] studied barriers to energy retrofitting of owner-occupied multi-family dwellings in nine European countries, not including Sweden, finding that collective decision problems is a challenge in every country and that lack of professional experience of real estate management is another challenge. Indeed, suboptimal decisions in co-ops can be costly [28].

As part of the strategy to tackle the housing need that existed before the 1960-1975 era, two cooperatives for groups of resident owned apartments were founded, HSB and Riksbyggen. 
These cooperatives constructed buildings that were sold to their member groups. The cooperatives also manage and maintain the resident-owned buildings. The cooperatives promote maintenance plans and certain types of renovations. The economic model may include a larger maintenance plan with more frequent visits and thus require less renovation projects.

After the Swedish bank crisis in 1991, privately owned rental apartments were converted into resident-owned apartments at an increased pace. It is more common with resident-owned buildings in attractive parts of the city, and the price increase of apartments in resident owned buildings has had a strong positive development during the past 20 years. During the same period, municipally owned multi-family dwellings have been sold to private capital funds in order to finance renovation and maintenance [29].

\section{Materials}

In this chapter, the materials from several Swedish authorities and institutions are described. Sampling was not necessary because $82 \%$ of the Gothenburg multi-family dwellings are covered by all matched datasets. Buildings were grouped based on the described ownership types and conversions.

\subsection{Matched Datasets}

Some datasets used for the analyses in this article were previously described in an article on the data quality of Swedish EPC data [30] and an article describing the renovation and energy retrofitting need in Gothenburg [31]. In these articles analyses of aspects related to the work behind this article such as data uncertainties can be found. Data on real-estate ownership was extracted from the Swedish National Land Survey and Retriever Business was matched with the EPC and base area socio-economic information. Base areas are the smallest demographical statistics area in Sweden containing 50 to 4000 residents. The combined geocoded datasets that describe the Gothenburg building stock are presented in Table 1.

Table 1. Details on datasets and data providers for multi-family dwellings in Gothenburg.

\begin{tabular}{|c|c|c|c|c|}
\hline & $\begin{array}{l}\text { The National Board of Housing } \\
\text { Building and Planning }\end{array}$ & Swedish Land Survey & $\begin{array}{l}\text { Gothenburg City } \\
\text { Executive Office }\end{array}$ & Retriever Business \\
\hline Aggregation level & Building & Building & Base area ${ }^{1}$ & Organization \\
\hline$N$ & 6320 & 64,600 & 434 & 1140 \\
\hline $\begin{array}{l}\text { Information used } \\
\text { in this article }\end{array}$ & $\begin{array}{l}\text { Heating and energy usage, identified } \\
\text { energy saving measures, number of } \\
\text { apartments, heated floor area }{ }^{3}\end{array}$ & $\begin{array}{c}\text { Construction year, renovation } \\
\text { year, value year }{ }^{2} \text {, building owner, } \\
\text { corporate form }\end{array}$ & $\begin{array}{l}\text { Average income, } \\
\text { number of inhabitants }\end{array}$ & $\begin{array}{l}\text { Organization } \\
\text { establishment year }\end{array}$ \\
\hline $\begin{array}{l}1 \text { Base areas } \\
\text { is further ex } \\
\text { Sweden }\left(A_{t e}\right. \\
\text { walls but no }\end{array}$ & $\begin{array}{l}\text { he smallest demographical sta } \\
\text { ned in } 3.1 \text { Renovation extent; }{ }^{3} \\
\text { Heated floor area is defined a } \\
\text { luding garages. }\end{array}$ & $\begin{array}{l}\text { stics area in Sweden contain } \\
\text { Heated floor area is a measu } \\
\text { the heated floor space inclu }\end{array}$ & $\begin{array}{l}\text { g } 50 \text { to } 4000 \text { resid } \\
\text { specifically deve } \\
\text { ng shared spaces }\end{array}$ & $\begin{array}{l}{ }^{2} \text { Value year } \\
\text { ped for EPC in } \\
d \text { footprints of }\end{array}$ \\
\hline
\end{tabular}

The Swedish Land Survey information contains the corporate form under which the building is owned. This makes it possible to separate the resident-owned buildings and the municipal housing companies. Due to legal limitations, socio-economic data had to be aggregated to base area level. For studies in 2019, it is recommended to aggregate sensitive socio-economic inhabitant information to the multi-family dwelling level.

\subsection{Characteristics of Building Ownership Groups}

The three tenure types are described in 1.1. Real estate ownership in Sweden was further subdivided to reflect differences in regard to the distinction between individual and social decision-making and area attractivity. The privately owned group was further subdivided into buildings owned by: private persons, private companies, or owned by foundations based on the distinction between individual and social decision making. To be noted is that student housing with a total heated floor area of $200,000 \mathrm{~m}^{2}$ is owned by foundations. 
Income was previously used as an indicator to geographically separate the city into more and less attractive areas in Gothenburg by Mangold et al. [31]. The threshold of average income of 200,000 SEK/year before tax was used to divide the ownership groups municipally owned and private company owned into dummy groups of more disadvantaged suburban areas or more attractive rental areas ( $1 \$=8.26$ SEK as of 1 March 2018). It should be noted that this separation does not reflect the official low-income definition, which is $60 \%$ of median income, $148,000 \mathrm{SEK} /$ year. The resident-owned buildings were divided into buildings that were built by the cooperatives for resident owned-buildings (HSB and Riksbyggen) and buildings that have been converted into resident-owned buildings. The details for the ownership groups can be seen in Table A2.

\subsection{Buildings Converted into Resident-Owned Buildings}

Retriever Business is a register of all companies in Sweden including organizations of resident-owned buildings, which contains establishment year. Most of the buildings registered as resident-owned in Retriever Business are registered as resident-owned in the Swedish National Land Survey - see Table A3 - but there are overlaps with other ownership groups due to a few different verified reasons: change of ownership between the records were made, split ownership of the building, and a company can own a share of a resident owned building. From 2000 to 2009 the buildings registered as resident owned increased from 901,000 to 2,280,000 $\mathrm{m}^{2}$ heated floor area. During the same time the group "private company owned, higher income" decreased from 3,380,000 to 2,550,000 $\mathrm{m}^{2}$ heated floor area. This made it possible to identify under which tenure renovations have taken place by comparing establishment year and reconstruction year.

\section{Methods}

The regressions were made to find and compare patterns of renovation investments and energy usage. The intention is to use these types of regressions for the assessment of building regulations and subsidy schemes in 2019. However, there are several other data analysis methods and visualization tools that are needed to communicate results with decision makers. The categorization of the building owners in this paper is an illustration of how to make the comprehensive building specific information more understandable. Timelines is another way to illustrate development that make it easy for practitioners, academics and decision makers to work together in the development of policy.

Regressions were made in $R$ to explain variance in renovation investments and energy performance, see Table 2. Renovation investments and energy performance were derived from value year and renovation year in the register of the Swedish National Land Survey and from the Energy Performance Certificates (EPC). The value year is initially the year of construction, but as the building is renovated, the value year will be changed depending on the cost of the renovation. This is further described in Table A4. The purpose of recording a value year is to have an official record of anticipated remaining service life of buildings [32].

Table 2. Description of models in the regression analyses.

\begin{tabular}{|c|c|c|c|c|}
\hline & Type & Dependent & Unit/Value & $N$ \\
\hline Model 1 & Ordinal & Renovation group & $0,1,2,3$ & 6244 \\
\hline Model 2 & Linear & Renovation extent & $\%$ & 6244 \\
\hline Model 3 & Linear & Energy performance & $\mathrm{kWh} / \mathrm{m}^{2}$.year & 5725 \\
\hline Model 4 & Linear & Energy performance excluding energy for heating domestic hot water & $\mathrm{kWh} / \mathrm{m}^{2}$.year & 5697 \\
\hline
\end{tabular}

\subsection{Renovation Investments}

In Sweden, renovations are registered on a municipal level. The Swedish Tax Office require that a renovation is registered as a change in value year depending on the cost of the renovation in relation to new building cost as described in Table A4 and Equation (1). New building cost is revised yearly by the Swedish tax authority to reflect inflation and changes in construction costs. 


$$
\text { Renovation extent }=\frac{\text { Renovation cost }}{\text { New building cost }}=\frac{\text { Value year }- \text { Construction year }}{\text { Renovation year }- \text { Construction year }}
$$

The groups in Table A4 were used in the ordinal (logit) regression in model 1. The groups are further described in Table A5. Using Equation (1), it was possible to calculate the renovation extent and equivalent cost of previous renovation projects from the value year and reconstruction year for group 2. The renovation extent was used as a dependent in model 2.

\subsection{Energy Performance}

Most EPCs for multi-family dwellings in Gothenburg were issued in 2008 and 2009 [30]. Since only one measurement of energy use is available from the EPC the statistical analysis for the relationship between building energy performance and investment in renovation the buildings were divided using renovation year of 2009 as a watershed. Energy performance of buildings renovated before 2009 include the impact of renovations. Only these buildings were used to analyze the importance of renovation investment for building energy performance, $N=5697$. The buildings renovated after 2009 were used to analyze the importance of energy savings advice provided in the EPC for renovation investments.

The EPC will be renewed in 2019. This will make it possible to replace energy performance with change in energy performance as a dependent in the future analyses of success and impact of changed building regulations and subsidy schemes.

Energy for heating domestic hot water is included in the energy performance presented in the EPC. However, regression analyses have been made for both energy performance including and excluding energy for heating domestic hot water. There is a large difference in registered heating for domestic hot water between the building ownership groups in Gothenburg (see Figure 1). Removal of outliers was conducted with the criterion 2.5 standard deviation above average buildings energy performance (223 and $182 \mathrm{kWh} / \mathrm{m}^{2}$.year for energy performance with and without energy for heating domestic hot water).

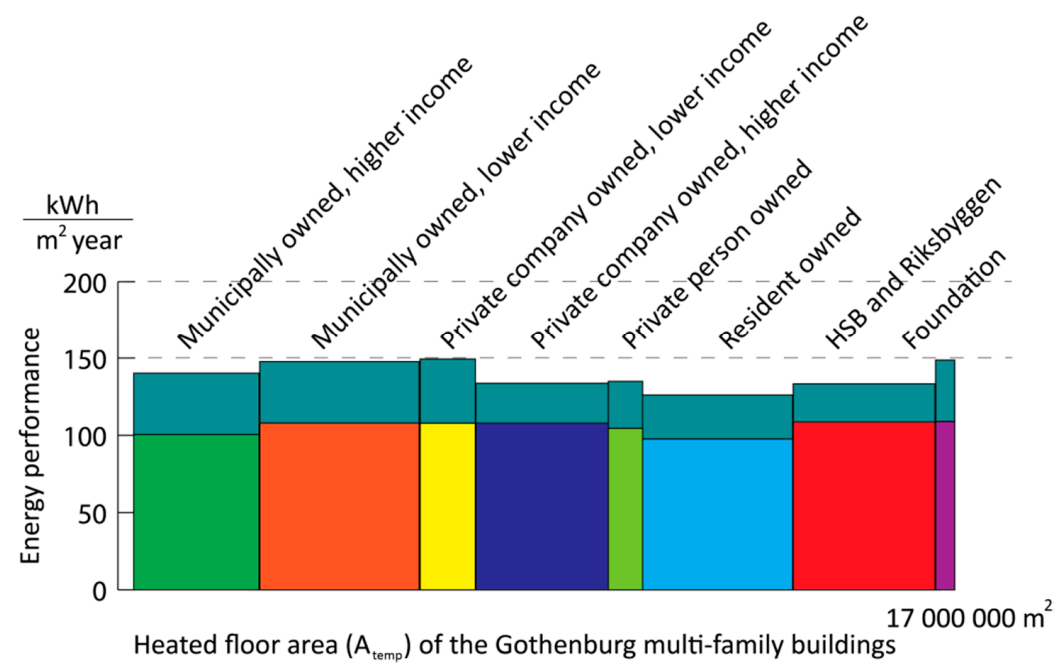

Figure 1. Energy usage in the Gothenburg multi-family dwellings separated into ownership groups. The energy for heating domestic hot water is teal.

Some studies suggest that water usage can be used as a proxy for number of inhabitants and time spent at home [33]. In Figure 1, the energy for heating of domestic hot water has been separated from the energy performance to illustrate the differences between the ownership groups. Living area per person has impact on both the need of renovation and on energy usage in buildings. 


\subsection{Independent Variables in Regression Analyses}

Nominal, ordinal, and scalar variables were used in the regression analyses. The independent variables building age, heating system, and ownership group are nominal variables that were converted into nominal groups of variables for the linear regression analyses. One variable in each group was kept outside of the linear regression analyses as a reference category; these are indicated with asterisk in Table A6. In the regression analyses, it was also possible to use base area average income as an independent variable instead of separating private company and municipal ownership into subgroups. For the statistical analyses of building energy performance, the importance of the time period in which the renovation happened was studied by creation an ordinal variable in segments 1979-1989, 1990-1999, and 2000-2009. This variable was excluded in the analyses of renovation investment because of the strong interdependence of the two variables both derived from renovation year.

\subsection{Robustness Checks}

In order to estimate renovation investments made in the entire building stock and be able to make a linear regression for the renovation costs, costs for renovations for group 1 and group 3 in Table A4 were assumed. The robustness of these assumptions was checked through the comparison between model 1 and 2, as well as an additional linear regression for only group 2. The assumptions caused no larger differences in the predictions.

Data on building ownership from Swedish National Land Survey only describe the building ownership in 2014. The changes in ownership were included by the addition of conversions registered in Retriever Business. The analysis of investment in relation to conversion was done only for the buildings registered in Retriever Business.

\section{Results}

Analyses of total costs and estimates of future cost of renovations and energy retrofitting were conducted by Mangold et al. [31]. In Figure 2, past renovation costs have been separated further in the ownership groups. A difference in how consistently the members in ownership groups invest in renovations can be seen and the economic crises in 1991 and 2000 are observable.

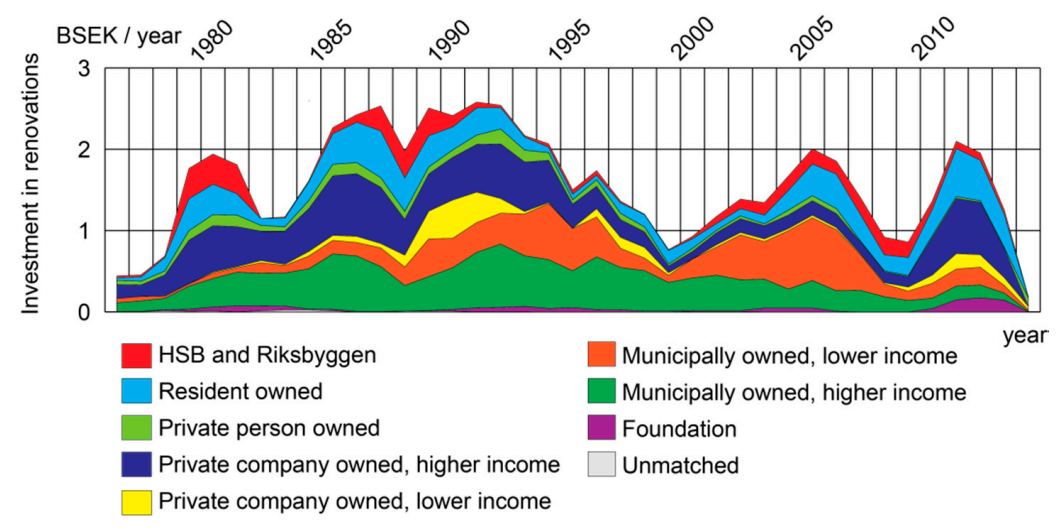

Figure 2. Costs of renovation registered for ownership groups.

The division of areas into higher and lower income is based on income statistics from 2015 which means that changes in income is not reflected in Figure 2. Some of the renovation costs in the municipally owned, higher income areas in the 1980ties and 1990ties were made in central areas that had a lower income level when they were renovated but are now higher income areas.

The renovation costs in Figure 2 include buildings from all construction periods. In the two largest ownership groups of multi-family dwellings constructed during 1960-1975-HSB and Riksbyggen and municipally owned, lower income - there is a considerable amount of multi-family dwellings 
that has not been renovated (see Table 3). The group resident-owned contain the most renovations that have been conducted with a cost of less than $20 \%$ of new building cost in Table 3. It is easier for resident that own their buildings to agree on and carry out smaller renovation investments than it is for other ownership groups.

For the discussion on municipal or private ownership of rental buildings in lower income areas, it is relevant to notice that private companies, and especially private persons, have registered fewer investments through renovations than municipal companies in Table 3.

Table 3. Share of heated floor area $\left(10^{3} \mathrm{~m}^{2}\right)$ in the renovation cost groups of the buildings built during 1960-1975.

\begin{tabular}{|c|c|c|c|c|c|}
\hline & No Renovation & Less than $20 \%$ & $20-70 \%$ & More than $\mathbf{7 0} \%$ & Grand Total \\
\hline Municipally owned, higher income & $44 \%$ & $20 \%$ & $9 \%$ & $26 \%$ & 398 \\
\hline Municipally owned, lower income & $50 \%$ & $23 \%$ & $20 \%$ & $6 \%$ & 2390 \\
\hline Private company owned, lower income & $50 \%$ & $38 \%$ & $9 \%$ & $3 \%$ & 745 \\
\hline Private company owned, higher income & $37 \%$ & $41 \%$ & $18 \%$ & $3 \%$ & 1019 \\
\hline Private person owned & $92 \%$ & $8 \%$ & $0 \%$ & $0 \%$ & 119 \\
\hline Resident owned & $30 \%$ & $55 \%$ & $12 \%$ & $2 \%$ & 570 \\
\hline HSB and Riksbyggen & $68 \%$ & $26 \%$ & $6 \%$ & $0 \%$ & 1358 \\
\hline Foundation owned & $74 \%$ & $12 \%$ & $3 \%$ & $12 \%$ & 167 \\
\hline Unmatched & $100 \%$ & $0 \%$ & $0 \%$ & $0 \%$ & 30 \\
\hline
\end{tabular}

In Figure 3, the renovation costs in relation to conversion to resident ownership have been illustrated. Right after the conversion renovation projects are the most frequent. Fewer buildings were renovated and then converted. In connection with the analysis of shared ownership (such as resident owned buildings) it was hypothesized that larger multi-family dwellings would be less renovated. However, a separation of the building stock in regard to building heated floor area did not show any significant relationship between resident owned buildings' size and renovation cost.

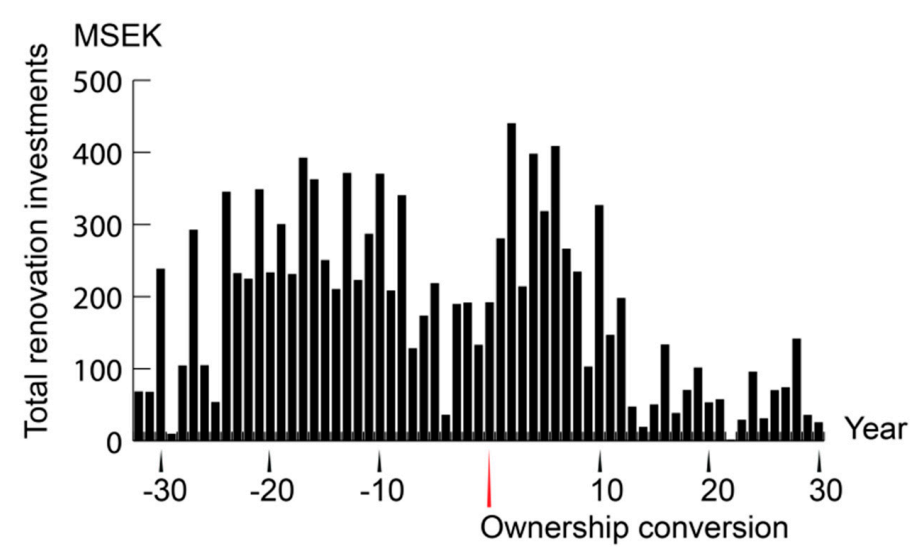

Renovation year in relation to ownership conversion

Figure 3. Costs of renovations of resident-owned building summed by the years between renovation year and the year the building tenure was converted into resident ownership, for only buildings registered as resident-owned in Retriever Business.

\section{Regression Results}

The coefficients in Table 4 mostly reflect expected patterns in the building stock of Gothenburg. This is a promising result for the later analysis of changes in energy usage connect using the same methods for the national building stock in 2019. However, there are also some important considerations to be made when applying these methods. 
Table 4. Ordinal (logit) and linear regression results.

\begin{tabular}{|c|c|c|c|c|c|c|c|c|}
\hline & Model 1 & & Model 2 & & Model 3 & & Model 4 & \\
\hline Variable & Estimate & Sig. & Coefficient & Sig. & Coefficient & Sig. & Coefficient & Sig. \\
\hline Constant & & & $73.594 * * *$ & 0.000 & $167.775^{* * *}$ & 0.000 & $132.131^{* * *}$ & 0.000 \\
\hline Renovation extent [\%] & & & & & $-0.084^{* * *}$ & 0.000 & $-0.092 * * *$ & 0.000 \\
\hline Energy performance $\left[\mathrm{kWh} / \mathrm{m}^{2}\right.$.year $]$ & $-0.007 * * *$ & 0.000 & $-0.156^{* * *}$ & 0.000 & & & & \\
\hline Private company owned & 0 & & & & & & & \\
\hline Municipality owned & $0.335 * * *$ & 0.000 & $3.018^{* *}$ & 0.010 & $8.089 * * *$ & 0.000 & -1.656 & 0.063 \\
\hline Private person owned & $-1.080 * * *$ & 0.000 & $-16.991 * * *$ & 0.000 & -0.116 & 0.935 & -1.56 & 0.094 \\
\hline Resident owned & $-0.475 * * *$ & 0.000 & $-11.061 * * *$ & 0.000 & -1.129 & 0.264 & 1.8 & 0.079 \\
\hline HSB and Riksbyggen & $-0.483 * * *$ & 0.000 & $-6.947^{* * *}$ & 0.000 & $-2.36^{*}$ & 0.034 & -0.222 & 0.866 \\
\hline Foundation owned & 0.106 & 0.560 & 5.331 & 0.065 & $19.369^{* * *}$ & 0.000 & $13.48^{* * *}$ & 0.000 \\
\hline Base area share of university degree [\%] & 0.094 & 0.572 & 0.005 & 0.437 & $7.503 * * *$ & 0.000 & $11.803 * * *$ & 0.000 \\
\hline Base area average income [KSEK] & $-0.001 * *$ & 0.005 & $-0.037^{* * *}$ & 0.000 & $-0.047^{* * *}$ & 0.000 & $-0.037^{* * *}$ & 0.000 \\
\hline Was recently renovated & & & & & $1.86^{* * *}$ & 0.000 & $1.27 * *$ & 0.005 \\
\hline FTX or other heat recovery from ventilation & $0.643^{* * *}$ & 0.000 & $6.041^{* * *}$ & 0.000 & $-2.865^{* *}$ & 0.007 & $-3.362 * * *$ & 0.001 \\
\hline District heating & 0 & & & & & & & \\
\hline Heat pumps & $-0.453^{* * *}$ & 0.000 & 1.521 & 0.502 & $-68.443 * * *$ & 0.000 & $-51.217^{* * *}$ & 0.000 \\
\hline Electricity & $-1.187^{* * *}$ & 0.000 & $-9.632 * *$ & 0.003 & $-32.891^{* * *}$ & 0.000 & $-29.621 * * *$ & 0.000 \\
\hline Boiler & $-0.335 * * *$ & 0.000 & $-7.85^{*}$ & 0.028 & $5.982 *$ & 0.028 & $6.413 *$ & 0.010 \\
\hline Constructed before 1945 & 0 & & & & & & & \\
\hline Constructed 1945-1960 & $-0.754 * * *$ & 0.000 & $-16.415^{* * *}$ & 0.000 & 0.511 & 0.628 & -1.049 & 0.279 \\
\hline Constructed 1960-1975 & $-1.631^{* * *}$ & 0.000 & $-35.937 * * *$ & 0.000 & 1.732 & 0.157 & -1.424 & 0.206 \\
\hline Constructed after 1975 & $-3.583 * * *$ & 0.000 & $-49.154^{* * *}$ & 0.000 & $-27.724 * * *$ & 0.000 & $-26.676^{* * *}$ & 0.000 \\
\hline Heated floor area $\left[10^{3} \mathrm{~m}^{2}\right]$ & 0.014 & 0.356 & -0.039 & 0.868 & $-0.852 * * *$ & 0.000 & $-0.564 * * *$ & 0.001 \\
\hline Sides with other buildings & -0.085 & 0.033 & -0.78 & 0.237 & $-5.325^{* * *}$ & 0.000 & $-4.3^{* * *}$ & 0.000 \\
\hline Number of floors & -0.026 & 0.107 & $-1.047^{* * *}$ & 0.000 & $-1.074^{* * *}$ & 0.000 & $-0.847 * * *$ & 0.000 \\
\hline Number of staircases & -0.006 & 0.559 & -0.061 & 0.701 & $-0.301 *$ & 0.015 & $-0.258 *$ & 0.024 \\
\hline Heated basements & $0.232 * * *$ & 0.000 & 0.463 & 0.621 & $-6.591 * * *$ & 0.000 & $-5.582 * * *$ & 0.000 \\
\hline Heated garage ratio to building [\%] & $-2.115^{* *}$ & 0.004 & $-31.77 * *$ & 0.001 & 1.096 & 0.832 & 6.279 & 0.191 \\
\hline$N$ & 6235 & \multirow{2}{*}{\multicolumn{3}{|c|}{$\begin{array}{c}6235 \\
\%\end{array}$}} & 5725 & & 5697 & \\
\hline Unit & & & & & \multicolumn{2}{|c|}{$\mathrm{kWh} / \mathrm{m}^{2}$.year } & \multicolumn{2}{|l|}{$\mathrm{kWh} / \mathrm{m}^{2}$.year } \\
\hline $\mathrm{R}^{2}$ adjusted & & \multicolumn{3}{|c|}{0.255} & \multicolumn{2}{|l|}{0.484} & \multicolumn{2}{|l|}{0.400} \\
\hline
\end{tabular}

* Coefficient is significant at the 0.05 level (2-tailed); ${ }^{* *}$ Coefficient is significant at the 0.01 level (2-tailed);

$* * *$ Coefficient is significant at the 0.001 level (2-tailed).

Models 3 and 4 explain variance in energy performance including and excluding heating for domestic hot water. This separation is important to make in order to understand why municipally owned multi-family dwellings have worse energy performance registered in the EPC than other ownership groups.

More costly renovations have resulted in lower energy usage, but buildings that have been renovated during the last decades have a higher energy usage when accounting for current heating system, ownership, and resident socio-economic background. As seen in Table 4, parts of the variance in energy performance are explainable by variables describing the energy systems of the buildings. The types of energy systems also differ between the ownership groups, as seen in Table 5 . This should also be considered when comparing the energy performance of the different ownership groups. The group heat pump stands out in the regression analysis because the energy supplied to the heat pump is recorded in the EPC, and not the energy provided by the heat pump to the building. Installation of ventilation with heat recovery and changing heating systems from electricity or boilers to heat pumps or district heating have been registered as renovations. Buildings constructed after the 1975 and after the oil crises were built with better energy performance.

Table 5 also illustrates how different ownership results in different types of energy savings measures. Installing heat pumps have been a profitable energy savings measure for especially private persons and residents owning their buildings. The price of district heating is close to the price of electric heating directly which incentivizes building owners to install heat pump. However, for municipal housing companies, buying district heat from waste heat and more carbon-neutral heating distributed by the municipal energy company is the most prevalent solution. Other commonly used energy savings measures in Sweden have been roof insulation, ventilation heat recovery, wall insulation, replacement of windows, and balcony heat bridge mitigation.

Table 4 also illustrates that municipally owned real estate companies make most of the larger investments in renovations. Fewer renovations are registered for resident owned buildings. Contributing factors to this pattern are that: parts of the renovations cost are shifted from the building owner to the apartment owner, ownership of the apartment reduces needs of maintenance, it is 
more difficult to agree on larger investments in larger groups of owners, HSB and Riksbyggen sell maintenance services which reduce the need for more costly renovations, and finally one unverified interpretation is that buildings built by HSB and Riksbyggen are in larger need of renovations.

Multi-family dwellings in base areas inhabited by economically disadvantaged people have a worse energy performance and fewer renovations have been made in these areas. This emphasizes the importance of including affordability aspects in the sustainability analysis of renovations of multi-family dwellings.

Table 5. Multi-family dwellings with different heat sources and energy efficient ventilation (FTX or heat recovery) in building ownership groups.

\begin{tabular}{|c|c|c|c|c|c|c|}
\hline & Boiler & District Heating & Electricity & Heat Pump & Total & $\begin{array}{c}\text { Energy Efficient } \\
\text { Ventilation }\end{array}$ \\
\hline Municipally owned, high income & 10 & 1020 & 13 & 26 & 1069 & 169 \\
\hline Municipally owned, low income & 0 & 810 & 9 & 1 & 820 & 86 \\
\hline Private company owned, low income & 1 & 293 & 2 & 8 & 304 & 40 \\
\hline Private company owned, high income & 13 & 975 & 14 & 38 & 1040 & 111 \\
\hline Private person owned & 5 & 368 & 9 & 26 & 408 & 15 \\
\hline Resident owned & 40 & 1188 & 67 & 165 & 1460 & 204 \\
\hline HSB and Riksbyggen & 18 & 908 & 0 & 65 & 991 & 104 \\
\hline Foundation owned & 0 & 140 & 1 & 11 & 152 & 25 \\
\hline Unmatched & 0 & 49 & 0 & 26 & 75 & 37 \\
\hline Grand Total & 87 & 5751 & 115 & 366 & 6319 & 791 \\
\hline
\end{tabular}

Separate statistical analyses were also made for the buildings renovated between 2009 and 2014 $(N=485)$. The EPCs were issued in 2009 , so for this analysis, the recorded energy performance was instead seen as a predictor of renovation. It was found that buildings with a poor energy performance were prioritized for larger renovations after 2009. The average building energy performance (excluding heating for domestic hot water) was $161 \mathrm{kWh} / \mathrm{m}^{2}$.year for renovation investment cost Group $3(N=17)$; compared with total average energy performance of $131 \mathrm{kWh} / \mathrm{m}^{2}$.year. However, it was not possible to establish a significant relationship between suggested energy saving measures and renovation extent.

For the statistical analysis of the socio-economic information, we found that using base area as a level of aggregation for socio-economic information introduces error sources and limitations for the interpretation of results. Existence of other building types made it difficult to establish clear links between number of residents in multi-family dwellings and base areas. Analyses that explain socio-economic status of areas would need to include information aggregated to the multi-family dwelling level.

\section{Discussion}

In this article methods of analyzing building-specific investment and energy performance have been described. The methods are intended to be used to present decision makers with analyses of developments in the multi-family dwelling stock. The interpretation of results is highly context specific and is also a political matter. Different subsidy schemes apply for the separate ownership groups and priorities in housing policy are based on political decisions.

Hsu [34] also used comprehensive building energy usage and engineering audits and found that variance in energy performance of buildings is not sufficiently explained by building and heating system characteristics. In this article we demonstrate that variance in building energy performance can be further described when adding building ownership and area socio-economic information. Huber et al. [20] studied the challenges of renovating and energy retrofitting multi-family dwellings in socio-economically disadvantaged areas. In this article, we find that the municipally owned real estate companies in Gothenburg are most exposed to those challenges. Trade-offs need to be made between energy usage reductions, rent increases, and increased living standards. Curtis et al. [35] used EPC data matched with census data for the Irish building stock, and found building energy performance to be worse in buildings in socio-economically disadvantaged areas. 
Michelsen et al. [23] found that larger real estate companies outperform smaller companies in terms of extensive renovations, but that smaller companies can be better at continuous maintenance. Company size was not part of the analysis in this article. However, we would like to add that the least number of renovations were registered for private person owned rental buildings. The municipally owned real estate companies are large, and they have executed most large renovation projects.

Matschoss et al. [17] compared energy efficiency renovations in multi-family dwellings in eight European countries with regard to building ownership, not including Sweden. They found that resident joint ownership may have internal barriers to making larger investments in energy retrofitting. In Sweden, the costs of renovating the interior of the resident owned apartments are not included in renovation cost of the entire building. Interior apartment renovations are frequent in resident owned buildings, due to the strong market development of resident owned apartments. Including these renovations costs and associated environmental impact would be necessary to make a more complete evaluation of multi-family dwelling resident ownership as a tenure type. Furthermore, other studies have shown that it is not possible to establish that energy usage cost calculations in the EPC affect the price of the resident owned apartments [36-39].

For rental apartments, the landlord-tenant problem can be a barrier to energy retrofitting and renovation [10,12-14]. It was difficult to isolate these aspects in the analysis of the Gothenburg multi-family dwellings. In Sweden, the real estate owner pays the heating cost. In the past decades, individual volumetric metering billing of electricity and water have been increasingly installed in rental apartments in Gothenburg [40].

Central for the regression analyses with building energy performance as dependent was the removal of domestic hot water heating. Only a minor share of the heat in domestic hot water remains in the building after usage. Most of the heat exits the building in the waste water [41]. Excluding heating for water usage from energy performance, which is most strongly predicted by living area per person $[33,40]$, is one manner of separating the impact of user behavior. When excluding energy for heating domestic hot water, no significant association between energy performance and building ownership could be made. This finding is relevant in the context that European countries are reissuing EPCs in which more countries will include measured, instead of calculated, energy and water usage. Because of the differences in water usage between the ownership groups, there are risks that groups of multi-family dwellings that are more crowded appear as have comparatively poorer energy performances depending on how the energy performance certification with measured energy usage is implemented in European counties.

\section{Conclusions}

This article analyzed variance in investments in renovations and building energy performance of multi-family dwellings, based on building ownership, location and building characteristics. We found that both building ownership and socio-economic area characteristics are useful in explaining variance. Central findings are that energy used for heating domestic hot water and heating systems varies between ownership groups and that municipally owned real estate companies face challenges in the renovation of building in socio-economically disadvantaged areas. Including affordability aspects in the sustainability analyses of larger renovations in such areas is necessary since economically disadvantaged groups are overrepresented in multi-family dwellings with poor energy performance. Buildings which have had higher energy usage are overrepresented in the group of buildings having gone through larger renovations in recent years. Large renovation is a predictor of lower energy usage. However, when accounting for current heating system, ownership, and resident socio-economic background, buildings that have been renovated during the last decades have a higher energy usage.

Building ownership is context specific, but the overall renovation progress and energy performance of buildings in different types of ownership groups can be described using official and publicly accessible databases. Comprehensive building specific information, separated in ownership groups, made it possible to demonstrate the differences in renovations and building 
energy performance between ownership groups. Furthermore, statistical analyses of the data can be used to reinforce conclusions.

\section{Future Studies}

The EPCs were designed to be renewed every 10 years. This will make it possible to describe and explain the changes in energy usage in Sweden in 2019. These studies will investigate predictors of energy retrofitting projects and changes in socio-economic inhabitation characteristics. Ideally, casual relationships can be made between these changes and changes in building regulation and subsidy schemes. In this study, sensitive socio-economic inhabitant information should be aggregated to the multi-family dwelling level during the time of the two waves of EPCs.

In this article, information about the Gothenburg multi-family dwelling stock has been studied. Johansson et al. [42] also used the information sources described in this paper to develop methods for connecting the entire Swedish national databases. This will make it possible to provide decision support to the national authorities which are responsible for building regulation and subsidy schemes.

Adding building-specific energy models would enable comprehensive strategic advice for building owners $[43,44]$. Using the records of renovation cost and energy performance linked with scenarios will make it possible to point out which building owners should be in line for energy retrofitting.

Author Contributions: M.M. wrote the article and did the statistical data analysis. M.Ö. provided support in writing and analysis of data. C.O. provided support in real estate economics and wrote the segments on 1.1 Real estate ownership in Sweden. T.J. did the merging of different data sources and helped in the writing of the paper. H.W. supervised the project, provided support in the writing and framed the paper as part of the research field.

Acknowledgments: The authors would like to thank Martin Storm at the National Board of Housing Building and Planning for sharing EPC data, Lutz Ewert at Gothenburg CEO for all discussions and for sharing socio-economic data and Eric Jeansson at CPA for giving us access to the Gothenburg spatial city plan. This work was financially supported by Chalmers Infrastructure Engineering, SIRen, and the Swedish Research Council for Environment, Agricultural Sciences and Spatial Planning-Formas. The Formas funds includes a budget post open access payment which will be used for this paper.

Conflicts of Interest: The authors declare no conflict of interest. The founding sponsors had no role in the design of the study; in the collection, analyses, or interpretation of data; in the writing of the manuscript, and in the decision to publish the results.

\section{Appendix A Tables with Descriptions of Ownership Groups and Variables for the Regression Analyses}

Table A1. Heated floor area of multi-family dwellings in Gothenburg divided by construction periods and ownership groups $\left[10^{3} \mathrm{~m}^{2}\right]$.

\begin{tabular}{|c|c|c|c|c|c|c|c|}
\hline & Built before 1931 & 1931-1945 & 1946-1960 & 1961-1975 & 1976-1990 & 1991-2005 & Built after 2005 \\
\hline Municipally owned, higher income & 512 & 383 & 788 & 398 & 320 & 169 & 76 \\
\hline Municipally owned, lower income & 34 & 31 & 746 & 2387 & 94 & 7 & 7 \\
\hline Private company owned, lower income & 21 & 21 & 351 & 745 & 1 & 1 & 17 \\
\hline Private person owned & 180 & 275 & 123 & 119 & 12 & 6 & 2 \\
\hline Resident owned & 919 & 467 & 402 & 590 & 194 & 235 & 252 \\
\hline HSB and Riksbyggen & 87 & 159 & 755 & 1358 & 346 & 183 & 51 \\
\hline Foundation owned & 58 & 19 & 43 & 167 & 9 & 66 & 41 \\
\hline Total & 2211 & 1980 & 3595 & 3049 & 1206 & 733 & 659 \\
\hline
\end{tabular}


Table A2. Descriptions of the ownership groups. Geographical analyses were conducted to verify the validity of the groups.

\begin{tabular}{|c|c|c|c|c|}
\hline & $\begin{array}{c}\text { Number of } \\
\text { Buildings }\end{array}$ & $\begin{array}{l}\text { Heated Floor Area } \\
\qquad\left[10^{3} \mathrm{~m}^{2}\right]\end{array}$ & $\begin{array}{l}\text { Average Income } \\
\text { [SEK/Person.Year] }\end{array}$ & Higher Education $^{1}$ \\
\hline Municipally owned, higher income & 1069 & 2646 & 241,000 & $44 \%$ \\
\hline Municipally owned, lower income & 820 & 3305 & 153,000 & $27 \%$ \\
\hline Private company owned, lower income & 304 & 1156 & 156,000 & $30 \%$ \\
\hline Private company owned, higher income & 1040 & 2729 & 263,000 & $48 \%$ \\
\hline Private person owned & 408 & 717 & 264,000 & $54 \%$ \\
\hline Resident owned & 1460 & 3059 & 283,000 & $52 \%$ \\
\hline HSB and Riksbyggen & 991 & 2939 & 243,000 & $38 \%$ \\
\hline Foundation owned & 152 & 403 & 238,000 & $68 \%$ \\
\hline Unmatched & 75 & 223 & 286,000 & $19 \%$ \\
\hline
\end{tabular}

Table A3. Retriever Business data description and overlap with data from Swedish National Land Survey.

\begin{tabular}{|c|c|c|c|c|c|}
\hline & $\begin{array}{c}\text { Buildings } \\
\text { Registered as } \\
\text { Resident Owned }\end{array}$ & $\begin{array}{c}\text { Heated Floor Area } \\
\text { in Retriever } \\
\text { Business }\left[10^{3} \mathrm{~m}^{2}\right]\end{array}$ & $\begin{array}{l}\text { Overlap of the } \\
\text { Datasets }\end{array}$ & $\begin{array}{c}\text { Average } \\
\text { Construction } \\
\text { Year }\end{array}$ & $\begin{array}{c}\text { Average } \\
\text { Organization } \\
\text { Registration Year }\end{array}$ \\
\hline Municipally owned, higher income & 53 & 147 & $6 \%$ & 1944 & 2004 \\
\hline Municipally owned, lower income & 1 & 1 & $0 \%$ & 1977 & 2005 \\
\hline Private company owned, lower income & 5 & 20 & $2 \%$ & 1931 & 2006 \\
\hline Private company owned, higher income & 185 & 578 & $21 \%$ & 1941 & 2004 \\
\hline Private person owned & 98 & 214 & $30 \%$ & 1937 & 2005 \\
\hline Resident owned & 696 & 1561 & $51 \%$ & 1944 & 1990 \\
\hline HSB and Riksbyggen & 94 & 481 & $16 \%$ & 1957 & 1956 \\
\hline Foundation owned & 7 & 10 & $3 \%$ & 1958 & 2006 \\
\hline
\end{tabular}

Table A4. Methods for setting a value year based on renovation costs according to Swedish Tax Agency [32].

\begin{tabular}{|c|c|c|}
\hline & Renovation Cost & Method of Setting the Value Year \\
\hline Group 1 & $\begin{array}{l}\text { Less than } 20 \% \text { of the new building } \\
\text { cost }{ }^{1} . \text { Assumed to be } 10 \% \text { in the } \\
\text { linear regression model. }\end{array}$ & No change in Value year \\
\hline Group 2 & $20-70 \%$ of the new building cost ${ }^{1}$ & $\begin{array}{l}\text { The value year is set based on the cost of the } \\
\text { renovation compared with the cost of constructing } \\
\text { a comparable building using Equation (1). }\end{array}$ \\
\hline Group 3 & $\begin{array}{l}\text { More than } 70 \% \text { of the new } \\
\text { building cost }{ }^{1} \text {. Assumed to be } \\
90 \% \text { in the linear regression model. }\end{array}$ & Value year is set to the year of the renovation \\
\hline
\end{tabular}

Table A5. Description of renovation cost groups. Renovation cost is presented as a percentage of New building cost as specified by the Swedish Tax Agency [32].

\begin{tabular}{ccccc}
\hline & Number of Buildings & Heated Floor Area $\left[\mathbf{1 0}^{\mathbf{3}} \mathbf{~ m}^{\mathbf{2}} \mathbf{]}\right.$ & Average Building Size $\left[\mathbf{m}^{\mathbf{2}}\right]$ & Average Construction Year \\
\hline No renovation & 3090 & 8050 & 2610 & 1966 \\
Group 1 & 984 & 3770 & 3830 & 1958 \\
Group 2 & 1040 & 2750 & 2640 & 1943 \\
Group 3 & 1210 & 2610 & 2160 & 1937 \\
\hline
\end{tabular}


Table A6. Independents in the regression analyses.

\begin{tabular}{ccccc}
\hline Type & Variable & Unit & Average & Std. dev. \\
\hline Nominal & Private company owned & Yes/no & 0.198 & - \\
Nominal & Municipality owned & Yes/no & 0.308 & - \\
Nominal & Private person owned & Yes/no & 0.068 & - \\
Nominal & Resident owned & Yes/no & 0.219 & - \\
Nominal & HSB and Riksbyggen & Yes/no & 0.170 & - \\
Nominal & Foundation owned/student housing & Yes/no & 0.025 & - \\
Scalar & Base area share of university degree & $\%$ & 0.433 & 0.196 \\
Scalar & Base area average income & KSEK & 238 & 64.7 \\
Ordinal & Was recently renovated (decades from 1988) & Ordinal & 0.924 & 1.18 \\
Nominal & FTX or other heat recovery from ventilation & Yes/no & 0.123 & - \\
Nominal & District heating 1 & Yes/no & 0.903 & - \\
Nominal & Heat pumps & Yes/no & 0.062 & - \\
Nominal & Electricity & Yes/no & 0.020 & - \\
Nominal & Boiler & Yes/no & 0.015 & - \\
Nominal & Constructed before 1945 1 & Yes/no & 0.353 & - \\
Nominal & Constructed 1945-1960 & Yes/no & 0.215 & - \\
Nominal & Constructed 1960-1975 & Yes/no & 0.224 & - \\
Nominal & Constructed after 1975 & Yes/no & 0.208 & - \\
Scalar & Heated floor area & $100^{3}$ m $^{2}$ & 2.63 & 2.97 \\
Ordinal & Sides shared with other buildings & Integer & 0.500 & 0.807 \\
Ordinal & Number of floors & Integer & 4.17 & 2.26 \\
Ordinal & Number of staircases & Integer & 3.58 & 3.89 \\
Ordinal & Number of heated basements & Integer & 0.700 & 0.494 \\
Scalar & Heated garage ratio to building & $\%$ o & 0.090 & 0.044 \\
\hline & 1 Variable used as reference category in the regression analyses. & \\
& & & &
\end{tabular}

\section{References}

1. IPCC. Working Group III—Mitigation of Climate Change, Chapter 9 Buildings. 2014. Available online: https: //www.ipcc.ch/pdf/assessment-report/ar5/wg3/ipcc_wg3_ar5_frontmatter.pdf (accessed on 28 April 2018).

2. EU (The European Union). Directive 2012/27/EU on Energy Efficiency; EU: Brussels, Belgium, 2012.

3. Meijer, F.; Itard, L.; Sunikka-Blank, M. Comparing European residential building stocks: Performance, renovation and policy opportunities. Build. Res. Inf. 2009, 37, 533-551. [CrossRef]

4. Ball, E. Holistic strategies for energy efficient refurbishment of the housing stock and renewal of the related energy supply system. In WP Transnational Manual; German Association for Housing, Urban and Spatial Development (DV): Berlin, Germany, 2011.

5. Heeren, N.; Jakob, M.; Martius, G.; Gross, N.; Wallbaum, H. A component based bottom-up building stock model for comprehensive environmental impact assessment and target control. Renew. Sustain. Energy Rev. 2013, 20, 45-56. [CrossRef]

6. Ostermeyer, Y.; Wallbaum, H.; Reuter, F. Multidimensional Pareto optimization as an approach for site-specific building refurbishment solutions applicable for life cycle sustainability assessment. Int. J. Life Cycle Assess. 2013, 18, 1762-1779. [CrossRef]

7. Pombo, O.; Rivela, B.; Neila, J. The challenge of sustainable building renovation: Assessment of current criteria and future outlook. J. Clean. Prod. 2016, 123, 88-100. [CrossRef]

8. Grossmann, K.; Kabisch, N.; Kabisch, S. Understanding the social development of a post-socialist large housing estate: The case of Leipzig-Grünau in eastern Germany in long-term perspective. Eur. Urban Reg. Stud. 2017, 24, 142-161. [CrossRef]

9. Corvacho, H.; Alves, F.B.; Rocha, C. A Reflection on Low Energy Renovation of Residential Complexes in Southern Europe. Sustainability 2016, 8, 987. [CrossRef]

10. Charlier, D. Energy efficiency investments in the context of split incentives among French households. Energy Policy 2015, 87, 465-479. [CrossRef]

11. Deng, Y.; Wu, J. Economic returns to residential green building investment: The developers' perspective. Reg. Sci. Urban Econ. 2014, 47, 35-44. [CrossRef]

12. Hope, A.J.; Booth, A. Attitudes and behaviours of private sector landlords towards the energy efficiency of tenanted homes. Energy Policy 2014, 75, 369-378. [CrossRef] 
13. Kholodilin, K.A.; Michelsen, C. The Market Value of Energy Efficiency in Buildings and the Mode of Tenure. Urban Stud. 2017, 54, 3218-3238. [CrossRef]

14. Pivo, G. Unequal access to energy efficiency in US multifamily rental housing: Opportunities to improve. Build. Res. Inf. 2014, 42, 551-573. [CrossRef]

15. Bardhan, A.; Jaffee, D.; Kroll, C.; Wallace, N. Energy efficiency retrofits for U.S. housing: Removing the bottlenecks. Reg. Sci. Urban Econ. 2014, 47, 45-60. [CrossRef]

16. Genus, A.; Theobald, K. Creating low-carbon neighbourhoods: A critical discourse analysis. Eur. Urban Reg. Stud. 2016, 23, 782-797. [CrossRef]

17. Matschoss, K.; Heiskanen, E.; Atanasiu, B.; Kranzl, L. Energy renovations of EU multifamily buildings: Do current policies target the real problems. In Rethink, Renew, Restart; IEEE: Piscataway Township, NJ, USA, 2013.

18. Ahlfeldt, G.M. Blessing or curse? Appreciation, amenities and resistance to urban renewal. Reg. Sci. Urban Econ. 2011, 41, 32-45. [CrossRef]

19. Arbaci, S.; Tapada-Berteli, T. Social inequality and urban regeneration in Barcelona city centre: Reconsidering success. Eur. Urban Reg. Stud. 2012, 19, 287-311. [CrossRef]

20. Huber, A.; Mayer, I.; Beillan, V.; Goater, A.; Trotignon, R.; Battaglini, E. Refurbishing residential buildings: A socio-economic analysis of retrofitting projects in five European countries. In Proceedings of the World Sustainable Energy Days, Wels, Austria, 2-4 March 2011; pp. 2-4.

21. Pagliaro, F.; Cellucci, L.; Burattini, C.; Bisegna, F.; Gugliermetti, F.; de Lieto Vollaro, A.; Salata, F.; Golasi, I. A methodological comparison between energy and environmental performance evaluation. Sustainability 2015, 7, 10324-10342. [CrossRef]

22. Hjortling, C.; Björk, F.; Berg, M.; Af Klintberg, T. Energy mapping of existing building stock in Sweden-Analysis of data from Energy Performance Certificates. Energy Build. 2017, 153, 341-355. [CrossRef]

23. Michelsen, C.; Rosenschon, S.; Schulz, C. Small might be beautiful, but bigger performs better: Scale economies in "green" refurbishments of apartment housing. Energy Econ. 2015, 50, 240-250. [CrossRef]

24. Albatici, R.; Gadotti, A.; Baldessari, C.; Chiogna, M. A decision making tool for a comprehensive evaluation of building retrofitting actions at the regional scale. Sustainability 2016, 8, 990. [CrossRef]

25. Šijanec Zavrl, M.; Stegnar, G.; Rakušček, A.; Gjerkeš, H. A bottom-up building stock model for tracking regional energy targets-A case study of kočevje. Sustainability 2016, 8, 1063. [CrossRef]

26. Hall, T.; Vidén, S. The Million Homes Programme: A review of the great Swedish planning project. Plan. Perspect. 2005, 20, 301-328. [CrossRef]

27. Castell, P. The Swedish Suburb as Myth and Reality; Chalmers University of Technology: Göteborg, Sweden, 2010.

28. Almenberg, J.; Karapetyan, A. Hidden costs of hidden debt. Rev. Financ. 2013, 18, 2247-2281. [CrossRef]

29. Lind, H. Does the Law on Rental Appartments Lead to Correct Renovations? (Leder Hyreslagens Regler Till Rätt Renoveringar: Analys Och Förslag). Available online: http:/ / www.renoveringscentrum.lth.se/ fileadmin/renoveringscentrum/SIRen/Publikationer/Leder_hyreslagens_regler_till_ratt_renovering.pdf (accessed on 28 April 2018).

30. Mangold, M.; Österbring, M.; Wallbaum, H. Handling data uncertainties when using Swedish energy performance certificate data to describe energy usage in the building stock. Energy Build. 2015, 102, 328-336. [CrossRef]

31. Mangold, M.; Österbring, M.; Wallbaum, H.; Thuvander, L.; Femenias, P. Socio-economic impact of renovation and energy retrofitting of the Gothenburg building stock. Energy Build. 2016, 123, 41-49. [CrossRef]

32. Swedish Tax Agency. The Tax Office General Advice (Skatteverkets Allmänna Råd); Swedish Tax Agency: Solna, Sweden, 2015.

33. Pullinger, M.; Browne, A.; Anderson, B.; Medd, W. Patterns of Water: The Water Related Practices of Households in Southern England, and Their Influence on Water Consumption and Demand Management; Lancaster University: Lancaster, UK, 2013; Available online: https://www.escholar.manchester.ac.uk/uk-ac-man-scw:187780 (accessed on 28 April 2018).

34. Hsu, D. How much information disclosure of building energy performance is necessary? Energy Policy 2014, 64, 263-272. [CrossRef] 
35. Curtis, J.; Devitt, N.; Whelan, A. Using census and administrative records to identify the location and occupancy type of energy inefficient residential properties. Sustain. Cities Soc. 2015, 18, 56-65. [CrossRef]

36. Bonde, M.; Song, H.-S. Is energy performance capitalized in office building appraisals? Prop. Manag. 2013, 31, 200-215. [CrossRef]

37. Bruegge, C.; Carrión-Flores, C.; Pope, J.C. Does the housing market value energy efficient homes? Evidence from the energy star program. Reg. Sci. Urban Econ. 2016, 57, 63-76. [CrossRef]

38. Cerin, P.; Hassel, L.; Semenova, N. Energy performance and housing prices. Sustain. Dev. 2012, $22,404-419$. [CrossRef]

39. Fuerst, F.; McAllister, P.; Nanda, A.; Wyatt, P. Energy performance ratings and house prices in Wales: An empirical study. Energy Policy 2016, 92, 20-33. [CrossRef]

40. Mangold, M.; Morrison, G.; Harder, R.; Hagbert, P.; Rauch, S. The transformative effect of the introduction of water volumetric billing in a disadvantaged housing area in Sweden. Water Policy 2014, 16, 973-990. [CrossRef]

41. McNabola, A.; Shields, K. Efficient drain water heat recovery in horizontal domestic shower drains. Energy Build. 2013, 59, 44-49. [CrossRef]

42. Johansson, T.; Olofsson, T.; Mangold, M. Development of an energy atlas for renovation of the multifamily building stock in Sweden. Appl. Energy 2017, 203, 723-736. [CrossRef]

43. Österbring, M.; Mata, É.; Thuvander, L.; Mangold, M.; Johnsson, F.; Wallbaum, H. A differentiated description of building-stocks for a georeferenced urban bottom-up building-stock model. Energy Build. 2016, 120, 78-84. [CrossRef]

44. Mastrucci, A.; Baume, O.; Stazi, F.; Leopold, U. Estimating energy savings for the residential building stock of an entire city: A GIS-based statistical downscaling approach applied to Rotterdam. Energy Build. 2014, 75, 358-367. [CrossRef]

(C) 2018 by the authors. Licensee MDPI, Basel, Switzerland. This article is an open access article distributed under the terms and conditions of the Creative Commons Attribution (CC BY) license (http:/ / creativecommons.org/licenses/by/4.0/). 